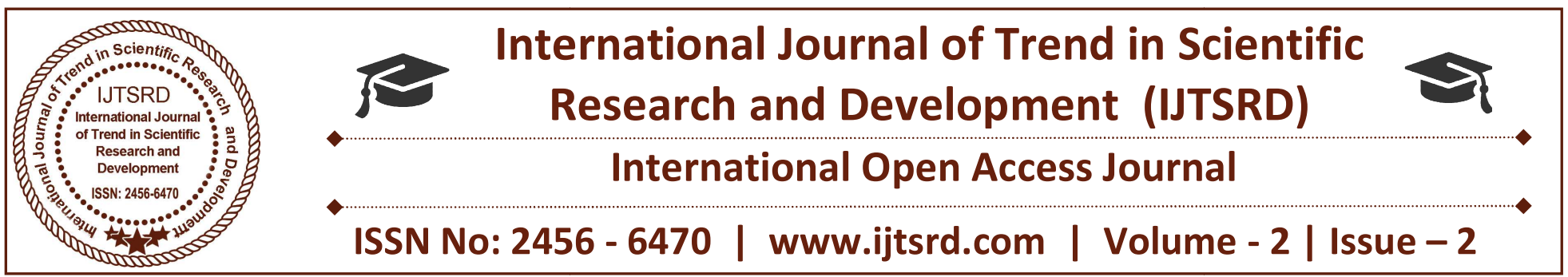

\title{
Impact of GST on the Indian Economy
}

\author{
Dr. C. J. Priya \\ Assistant Professor, Vidya Vikas First Grade College \\ Mysore, Karnataka, India
}

\author{
Harshitha M C \\ Assistant Professor, Vidya Vikas First Grade College, \\ Mysore, Karnataka, India
}

\section{ABSTRACT}

GST the biggest Tax Reform in India founded on the notion of "One Nation, One Market, One Tax" is finally here. The movement that the Indian government was waiting for the decade has finally arrived. The single biggest Indirect tax regime has kicked into force, dismantling all the inter-state barriers with respect to trade. The GST rollout, with the single stroke, has converted India into a unified market of 1.3 billion citizens. The idea behind implementing GST across the country in 29 states \& 7 union territories is that it would offer a win- to-win situation for everyone. Manufacturers \& Traders would benefit from fewer tax filing, transparent rules \& easy booking; consumers would pay less for the goods \& services and the government would generate more revenues. So this paper tries to throw a light on various aspects of GST and to know its probable impact on Indian economy and its sectors. The data are collected through various secondary sources like reports of Government, professional bodies, working committees and also from research papers, articles, news, budget sessions etc.

Keywords: GST, Indian Economy, Tax Reform

\section{INTRODUCTION:}

The Goods and Services Tax (GST) is a vast concept that simplifies the giant tax structure by supporting and enhancing the economic growth of a country. GST is a comprehensive tax levy on manufacturing, sale and consumption of goods and services at a national level. The introduction of Goods \& Service
Tax is a very significant step in the field of Indirect Tax reform in India. By amalgamating a large number of Central \& State taxes, it has mitigated cascading effect or double taxation in a major way $\&$ has paved way for a common national market. From the consumer point of view, the biggest advantage is in the terms of reduction in the overall tax burden on Goods \& Services.

Indian economy is getting more globalised over the past two decades. Introduction of an Integrated Goods and Service Tax (GST) to replace the prevailing multiple tax structures of Centre and State taxes is very imperative in the changing economic environment. The proposed GST is expected to bring the changes in the whole scenario of current indirect tax system. Moving towards GST is the biggest tax reform in the post liberalized economy. The proposed GST is likely to unify the entire multiple and complex taxes under one umbrella and will create a smooth national market. GST is expected to help the economy to grow more efficiently by improving the tax collection by disrupting all the tax barriers between states and integrate country through a single tax rate. GST was introduced for the first time by France in 1954 and now more than 160 countries have adopted GST. Most of the countries followed unified GST while some countries like Brazil, Canada follow a dual GST system where tax is imposed by central and state both. Being the consumption type of VAT, the GST has integrate tax on goods and services across all supply chain for availing set-off and capture value addition at each stage. By doing so, GST has 
eliminated the burden of all cascading effects from original producer up to the retailer level.

\section{RESEARCH PROBLEM:}

The concept of Goods and Services Tax (GST) is the biggest tax reform in decades throughout the world, but India has been taking baby steps to meet its target of rolling out goods \& services tax (GST) on April 1, 2016. The research intends to focus on understanding concept of goods and service tax and its impact on Indian economy.

\section{OBJECTIVES OF THE STUDY:}

1. To study and understand the concept of Goods and Services Tax (GST) and its impact on Indian Economy.

2. To know the benefits of GST to Indian economy, consumers, industry and business.

3. To analyze the challenges of GST in Indian context.

\section{RESEARCH METHODOLOGY}

The study focuses on extensive study of Secondary data collected from various books, National \& international Journals, government reports, publications from various websites which focused on various aspects of Goods and Service tax.

\section{GST RATES:}

The GST will apply at 5 basic rates., $0 \%$ will apply to essential food items, exports and supply to special economic zones. $0.25 \%$ on rough diamond, $3 \%$ on gold, 5\% will apply to some mass consumption items, $12 \%$ rate will apply to other commonly used items such as soaps, cell phones, processed foods, $18 \%$ standard rate which will apply to most products and services, $28 \%$ will apply to durable consumer goods such as television and cars.

\section{POSITIVE IMPACTS ON THE ECONOMY:}

Implementation of a single National GST will have major beneficial impact on all stake holders. The key highlight of such impact is given below:

\section{- Eliminates cascading effect \& barrier free tax structure:}

GST will eliminate cascading [tax on tax/ compounding tax] impact on the production and distribution cost of goods and services. This reduced cost of goods and service leading to accelerated GDP growth. GST without tax barriers will leads to economies of scale in manufacturing industry and reduces the supply chain cost.

\section{- Expected to reduce the production cost:}

GST is expected to reduce the production cost by $15 \%$ to $20 \%$ in many of the products in view of full input tax credit which will have favorable impact on the prices of product.

\section{- Expected to increase the tax revenue:}

GST will widen the tax base and improve the tax compliance higher tax: GDP ratio. The Tax: GDP ratio is expected to increase by $2 \%$ as per FRBM report. This works out to rupees 70,000 to 80,000 crores of additional annual revenue to the central and state governments. Introducing GST and Its Impact on Indian Economy 103

\section{- Leads to sustainable growth in the economy:}

GST will remove the tax distortions from the economy. This will lead to sustainable higher growth based on competitive strength of the country. Simple tax system will attract more productive investment for growth.

- Will lead to optimization and comparative cost advantage:

GST will eliminate the Inter State tax by which it will leads to optimization of physical facilities to the extent of full capacity. If the manufacturing is done at full capacity industry will be benefited by comparative cost advantage.

\section{- Increase in the GDP and standard of living:}

Since it is expected that with the implementation of GST the price level will reduced in the economy, it will results in increase in the consumption level and growth in GDP of the economy. According to study by NCAER (National Council for Applied Economics and Research) complete implementation of GST could lift GDP growth by $0.9-1.7 \%$.

\section{- Positive effects on export and BOP level:}

In proposed GST the exporter will get the full tax credit, the export units will be able to quote better price for their products and services in comparison with present scenario. Increased export will ultimately have positive effect on the BOP of the country. 
- Leads to Unique price and removes inequalities between the markets:

As GST will leads to imposition of same tax rate on the goods and services everywhere in the country and by implementing same tax rate it will removes the inequalities between the market which we can seen in the market at present because of the tax rate differentials.

\section{- Will lead to reduced chance for tax evasion:}

Since the proposed GST will charges full tax on the each and every transfer, it's difficult for the firms to evade tax from the payment. E.g.: e-commerce firms can't evade tax by operating business from the place where tax rates are comparatively less.

\section{- Leads to centralized where housing for manufacturers:}

In the present tax system if the dealer and the ware house are from different states, then the dealer needs to pay a Central Sales Tax of about $2 \%$.This will increases the price of the commodity. Thus companies use to setup a warehouse in each state. In GST as the CST gets eliminated, the centralized where housing can be availed by the manufacturers. 104 Introducing GST and Its Impact on Indian Economy

- Makes the tax structure simple and reduces the compliances:

Multiple taxes that currently exist will no longer remain in the picture. This will reduces the compliances to be fulfilled as compared to present situation.

\section{NEGATIVE SIDE OF GST ON INDIAN ECONOMY:}

The proposed GST may lead to following negative impact on the stake holders:

- Negatively affect the price level of essential goods and services:

The proposed GST may lead to increase the price of essential products and services which are presently exempted from the taxation.

\section{- Negative effect on the real estate industry:}

As per the study undertaken by the Curtin University of Technology, Perth in 2000, GST would negatively impact the real estate market as it would add up to $8 \%$ to the cost of new homes and reduce demand by about $12 \%$.
- Negative effect on working capital:

As the firms are suppose to make the payment of the tax on every transfer the companies working capital requirement will shoots up by proportional to the purchase of inputs for the value addition.

\section{- Emergence of transfer pricing issues:}

As the GST considers all the transaction for taxation purpose, this procedure will increases the price of the transfer from one department to another for further process.

\section{BENEFITS OF GST}

\section{FOR BUSINESS AND INDUSTRY:}

- Easy Compliance: A robust and comphrensive IT system would be the foundation of GST regime in India. Therefore, all tax payer services such as registration, return filing, payment etc., would be available to tax payers online, which has made compliance easy and transparent.

- Uniformity of tax rates and structures: GST will ensure the indirect tax rate and structure are common across the country. Thereby increasing certainty and easy of doing business. In other words, GST would make doing business in the county tax neutral, irrespective of the choice of place of doing business.

- Removal of cascading effect: A system of seamless tax credits throughout the value chain, and across boundaries of states, would ensure that there is minimial cascading of taxes. This would reduce hidden cost of doing business,

- Improved competitiveness: Reduction in transaction cost of doing business would eventually lead to an improved competitiveness for the trade and industry.

- Gain to manufacturers and exporters: The subsuming of major central and state taxes in GST, complete and compressive set of input goods and services and phasing out of Central Sales Tax would reduce the cost of locally manufactured goods and services. This will increase the competiveness of Indian goods and services in the international market and give boost 
to Indian exports. The uniformity in tax rates and procedures across the country will also go a long way in reducing the compliance cost.

\section{FOR CONSUMERS}

- Single and transparent tax proportionate to the value of goods and services:

Due to multiple indirect taxes being levied by the central and state, with incomplete or no input tax credits available at progressive stages of value addition, the cost of most goods and services in the country today our laden with many hidden taxes. Under GST, there is only one tax from the manufacturer to the consumer, leading to transparency of taxes paid to the final consumer.

- Relief in overall tax burden: Because of efficiency gains and prevention of leakages, the overall tax burden on most commodities will come down which will benefit the consumers.

\section{SUGGESTION AND CONCLUSION}

Implementation of GST is one of the best decisions taken by the Indian government. For the same reason, July $1^{\text {st }}$ was celebrated as Financial Independence Day in India. The transition to the GST regime which is accepted by 159 countries would not be easy. Confusions and complexity were expected and will happen. India, at some point, had to comply with such regime. Though this structure might be a perfect one but once in place, such a tax structure will make India a better economy favorable for foreign investments. Until now, India was a union of 29 small tax economies and 7 union territories with different levies unit to each state. It is a much accepted and appreciated regime because it does away with multiple tax rates by centre and state.

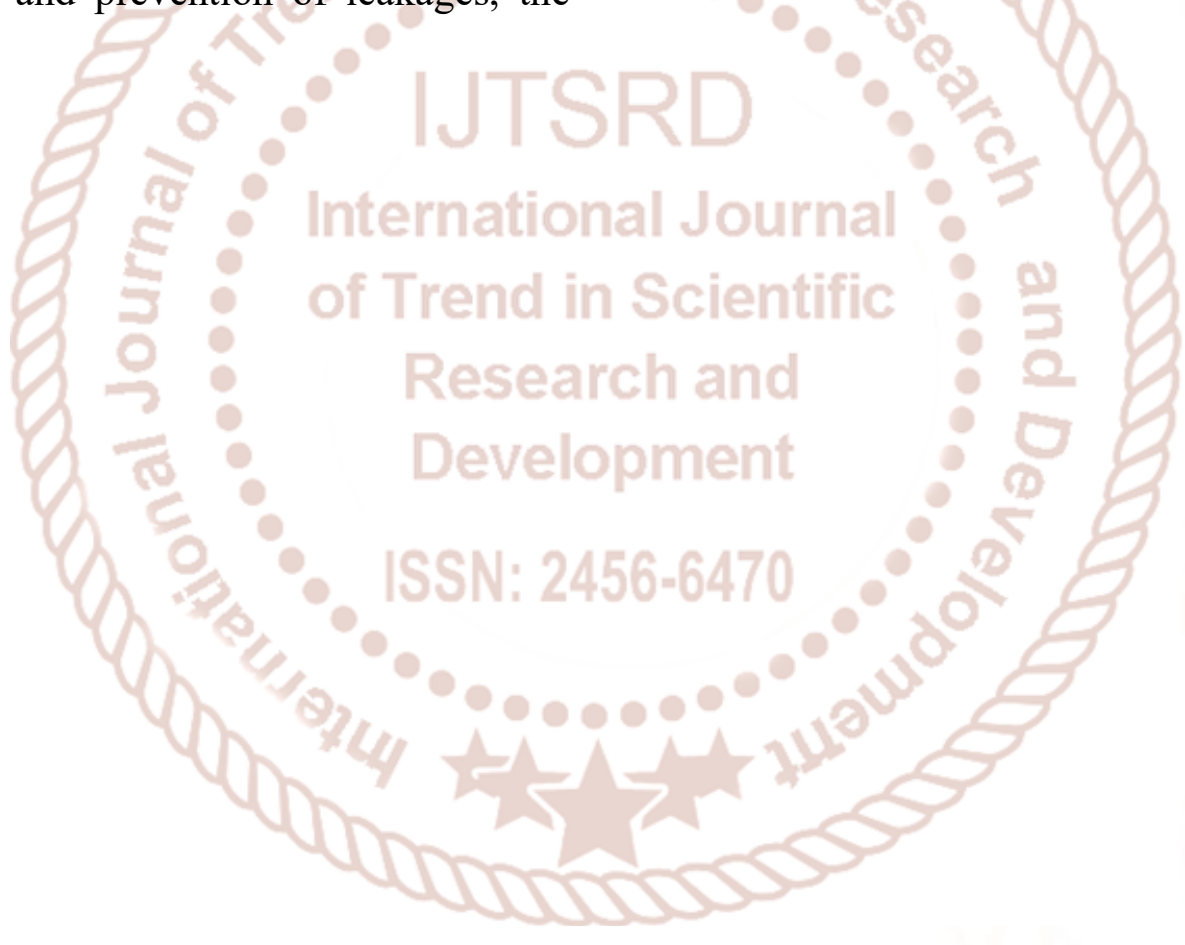

